\title{
The effect of arbuscular mycorrhizal fungus on morphological characters and yield of cayenne pepper (Capsicum frutescens $L$.)
}

\author{
Fredy Lala*, Yulistiawati Jasil, Kisey Habeahan, Himawan Bayuaji, and Abdul Wahab \\ Assessment Institute of Agricultural Technology of North Maluku, Sofifi, North Maluku, Indonesia
}

\begin{abstract}
Fluctuations in cayenne pepper (Capsicum frutescens L.) yields are often a contributs to inflation in North Maluku. The addition of Mycorrhiza Arbuscular Fungus (AMF) can optimize the production of $C$. frutescens to suppress production fluctuations. The study aimed to determine the best dose of AMF for the growth and yield of $C$. frutescens. The research was conducted from April to October 2020 at AIAT North Maluku greenhouse. The study was arranged using Completely Randomized Design. Five level dosages of AMF were 0.0, 3.0, 6.0, 9.0 and $12.0 \mathrm{~g}$ per plant. Each treatment was repeated four times. The results showed that the application of AMF increased plant height, number of leaves, yield, and fruit weight of Capsicum frutescens. AMF treatment at a dosage of $9 \mathrm{~g} / \mathrm{plant}$ gave the highest yields on the number of fruits $(50.39 \mathrm{pcs})$, fruit weight $(36.79 \mathrm{~g})$, root length $(89 \mathrm{~cm})$, root wet weight $(87.5 \mathrm{~g})$, and infection mycorrhizae (94\%). The dosage of AMF $9 \mathrm{~g} /$ plant had a significant effect $(\mathrm{P}<0.05)$ on the number and weight of $C$. frutescens fruit, length and weight of wet roots, and the percentage of mycorrhizal infection. The research implication is that the optimal dose of AMF can be a biological stimulating agent to increase plant growth and yield.
\end{abstract}

\section{Introduction}

Cayenne pepper (Capsicum frutescens L.) is a commodity where the supply and demand in the North Maluku market are often unbalanced, triggering high prices and contributing to inflation [1]. The limited availability of $C$. frutescens in the market is also due to low yields at the farmer's level. The planting area of $C$. frutescens in North Maluku in 2018 was around 2,133 ha, while the production was 4,661 tons [2]. Up to now $C$. frutescens cultivation has not been managed optimally, even though the growth of $C$. frutescens plants is highly dependent on the availability of nutrients [3] and effectiveness of production inputs [4].

AMF is a biological fertilizer containing live mycorrhizal spores and propagules in a mutualistic symbiosis with plant roots. According to Basu et al. [5] the relationship between plants and fungi is described as a reciprocal relationship where carbohydrates are supplied by plants for fungal metabolic activities while plants are supplied with nutrients and water by fungi for growth so that the relationship between fungi and plants is a mutually beneficial

* Corresponding author: fredylala69@gmail.com 
symbiotic association. Cysteine-rich mycorrhizal protein (MISSP7) plays an important role in facilitating reciprocal interactions between mycorrhizal fungi and host plants [6]. The provision of AMF in addition to having a positive impact on plant growth can also increase resistance to drought and soil-borne pathogens [7].

The benefits of AMF on C. frutescens plants in North Maluku are still very limited. Therefore, this study is very important with the aim of knowing the best dosage of AMF for the optimum growth and highest yield of $C$. frutescens.

\section{Materials and methods}

The research was carried out in the North Maluku AIAT greenhouse, Kusu Village, North Oba District, Tidore Islands City, North Maluku from June to October 2020. The study was arranged using completely randomized design with five treatments and four replications. The variety of $C$. frutescens used in this experiment was CF 291. The soil used as a planting medium has a low nutrient content based on analysis [8]. Soil (6 kg/polybag) mixed with goat manure as much as $2 \mathrm{~kg}$ per polybag $(20 \times 25 \mathrm{~cm})$ as a planting medium.

AMF treatment of five dosages, i.e. $\mathrm{M} 0=0.0 \mathrm{~g} / \mathrm{plant}, \mathrm{M} 1=3.0 \mathrm{~g} / \mathrm{plant}, \mathrm{M} 2=6.0 \mathrm{~g} / \mathrm{plant}$, $\mathrm{M} 3=9.0 \mathrm{~g} /$ plant and M4 $=12.0 \mathrm{~g} /$ plant applied before the seedlings transplanted to polybags. The AMF applied was in the form of zeolite granules containing five species of endomycorrhizae. The age of $C$. frutescens seedlings when transferred to polybags is 30 days. Fertilization following the recommendation is to use NPK (16:16:16) at a dosage of $10 \mathrm{~g} / \mathrm{l}$ of water then mixture was applied as much as $200 \mathrm{ml} /$ plant at 10-day intervals [9]. Pest and disease control is carried out physically (use a paintbrush to remove aphids on the leaves and shoots of the plant and scissors to remove any rotting parts of the stems).

Observation of morphological characters of $C$. frutescens $(n=60)$ consisted of plant height and number of leaves measured eight times manually with an interval of once a week. Observation begins on April 27, 2020 or one week after planting. Likewise, the number of fresh fruit, the number of rotten fruit, and the weight of fresh fruit were observed in 13 harvests with an interval of once a week. Root length, wet root weight, and observation mycorrhizal infection based on clearing and staining technique following the method of Kormanik and Mc Grow [10]. Morphological characters observation data and yields were processed by descriptive analysis and analysis of variance (ANOVA) and Least Significance Different (LSD) test.

\section{Results and discussion}

\subsection{Plant height and number of leaves}

Cayenne pepper plant height shows an increase with increasing plant age (Figure 1). Plant height shows an exponential growth trend, from the initial measurement to the end. Plants treated with AMF and control both showed a similar growth trend in plant height (Figure 1).

The application of the same manure and inorganic fertilizer as recommended on plants with different AMF treatments has not resulted in a significant difference (non-significant) (Table 1). This indicates that although the plants were given five different AMF treatments, each of them received sufficient food. Statistically it did not show any difference, but it can be seen that the treatment of $9 \mathrm{~g} /$ plant was the best compared to other treatments including the treatment of $0 \mathrm{~g} /$ plant which produced the lowest plant height (Table 1). Without AMF, plant height growth is not optimal because the uptake of available nutrients cannot be optimally absorbed by plant roots. 
AMF in untreated C. frutescens plants (M0) can come from the soil where they grow and can have a positive impact on plants even though they are not as effective as those treated. The results of the study conducted by Astiko et al. [7] proved that the application of AMF played a an important role in improving the quality of the growing media and the absorption of nutrients N, P, K, Ca, and microelements by plant roots. According to Halis et al. [11], plant height was strongly influenced by the dosage of AMF.

The provision of balanced fertilization can affect plant growth. The amount of nutrient $\mathrm{N}$ that is available and absorbed by the roots will affect root and stem biomass and plant height $[10,12]$, while the element $\mathrm{P}$ plays a very important role in the process of cell division, reproduction, metabolism, acquisition, storage, and use of energy [13]. If there is a deficiency of $\mathrm{N}$, the plant height, root diameter, chlorophyll, and carotene content will be lower [13].

The number of leaves from all AMF treatments also showed a similar trend (Figure 2). Even though all the AMF treatments did not show any difference, the dose of $9 \mathrm{~g} / \mathrm{plant}$ was the best treatment (Table 1). Giving AMF with the highest dosage (12 g / plant) turned out to be high-yielding plants that are better than $0 \mathrm{~g} /$ plant. The number of leaves is closely related to leaf area, where the more the number of leaves, the larger the leaf area. If the availability of $\mathrm{N}$ is absorbed by $\mathrm{AMF}$, it can affect leaf size because $\mathrm{N}$ is an important element in the formation of chlorophyll, protoplasm, protein, and nucleic acids [14]. So, at a dosage of $9 \mathrm{~g} /$ plant that produced the highest number of leaves, chlorophyll, protoplasm, protein, and nucleic acids were formed optimally.

This is closely related to the performance of AMF, as stated by McFarland et al. [15], that more than $50 \%$ of plant $\mathrm{N}$ needs are supplied by mycorrhizal associations and the increase in plant dry weight is influenced by vegetative growth of the plant itself such as plant height and leaf area. The same thing was conveyed by Nurhayati [16], that mycorrhizae were able to increase the dry weight of rice plants by two times compared to rice without mycorrhizae.

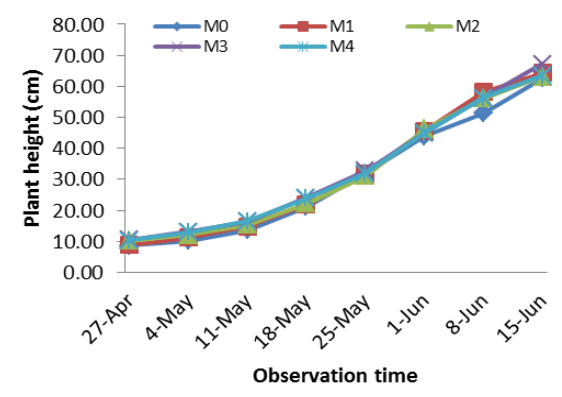

Fig. 1. Plant height of Capsicum frutescens

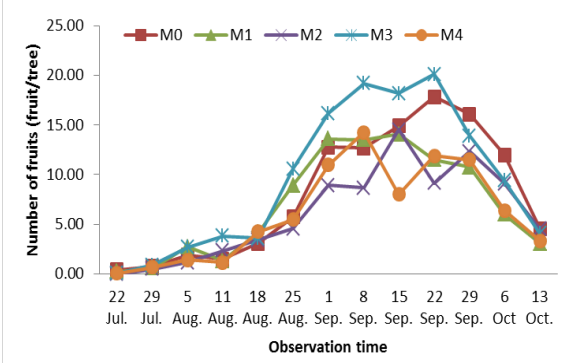

Fig. 3. The yields of Capsicum frutescens

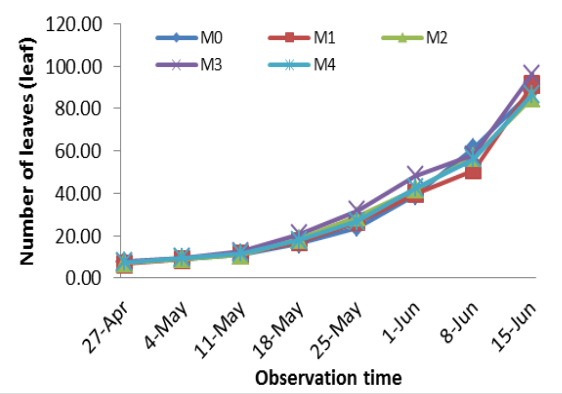

Fig. 2. Number of leaves Capsicum frutescens

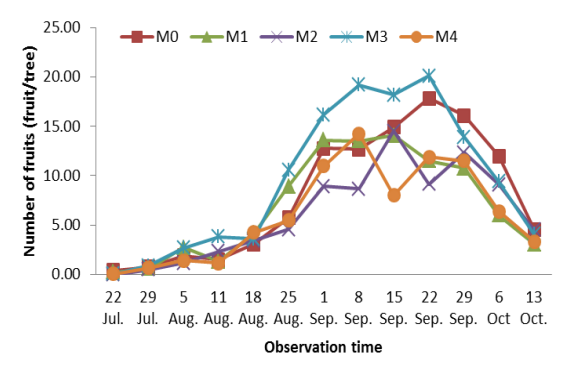

Fig. 4. The weight of Capsicum frutescens 


\subsection{The yields and weight of capsicum frutescenss}

The number of $C$. frutescens produced in 13 harvests fluctuates (Figure 3), almost the same thing happened to the weight of the fruit (Figure 4). The peak yield and the highest fruit weight were achieved at the 10th harvest (AMF dose $9 \mathrm{~g} / \mathrm{plant}$ ), after which it began to decline until the 13th harvest.

The application of AMF with different doses resulted in a significant difference $(\mathrm{P}<0.05)$ between treatments (Table 1). The dose of $9 \mathrm{~g} /$ plant was the best treatment and produced the highest number and weight of $C$. frutescens. At this dose, nutrient uptake by roots in soils with low nutrient content is optimal because according to Garg et al. [17] AMF can help expand the functionality of the root system in obtaining nutrients on degraded land and increase plant growth despite low soil fertility.

The harvesting process is closely related to the ability of AMF to absorb nutrients, especially P, which according to Bucking et al. [18], and Parihar et al. [19] orthophosphate or inorganic phosphate transporter (Pi) present in AMF Glomus versiformis can explore nutrient phosphate (P) through mycelium (hyphae) and deliver it to plant cortical cells. The small diameter of the AMF hyphae penetrates the soil core to find and store $\mathrm{P}$ in the form of polyphosphate which allows AMF to maintain a lower Pi concentration and then more efficient $\mathrm{P}$ transfer, production, and secretion of acid phosphatase and organic acids that play a role in the release of $\mathrm{P}$ from organic complexes.

Table 1. Analysis of vegetative and generative growth of Capsicum frutescens

\begin{tabular}{|c|c|c|c|c|c|c|}
\hline No. & Treatment & $\begin{array}{c}\text { Plant } \\
\text { height } \\
\text { (cm) }\end{array}$ & $\begin{array}{c}\text { Number of } \\
\text { leaves (blade/ } \\
\text { plant) }\end{array}$ & $\begin{array}{c}\text { Number of } \\
\text { fruits per plant } \\
\text { (fruit) }\end{array}$ & $\begin{array}{c}\text { Fruit } \\
\text { weight } \\
\text { (g/plant) }\end{array}$ & $\begin{array}{c}\text { Number of } \\
\text { rotten fruits per } \\
\text { plant (fruit) }\end{array}$ \\
\hline 1. & M0 & $62.55 \mathrm{a}$ & $88.34 \mathrm{a}$ & $34.75 \mathrm{ab}$ & $22.97 \mathrm{~b}$ & $4.42 \mathrm{a}$ \\
\hline 2. & $\mathrm{M} 1$ & $64.33 \mathrm{a}$ & $91.33 \mathrm{a}$ & $30.17 \mathrm{~b}$ & $19.14 \mathrm{~b}$ & $3.95 \mathrm{a}$ \\
\hline 3. & $\mathrm{M} 2$ & $63.17 \mathrm{a}$ & $85.25 \mathrm{a}$ & $26.39 \mathrm{~b}$ & $17.23 \mathrm{~b}$ & $3.17 \mathrm{a}$ \\
\hline 4. & $\mathrm{M} 3$ & $67.21 \mathrm{a}$ & $96.42 \mathrm{a}$ & $50.39 \mathrm{a}$ & $36.79 \mathrm{a}$ & $1.05 \mathrm{a}$ \\
\hline 5 & $\mathrm{M} 4$ & $63.50 \mathrm{a}$ & $86.75 \mathrm{a}$ & $26.50 \mathrm{~b}$ & $17.74 \mathrm{~b}$ & $3.67 \mathrm{a}$ \\
\hline & $\mathrm{CV}(\%)$ & 17,19 & 16,57 & 18,05 & 17,22 & 13,63 \\
\hline
\end{tabular}

Mean which are not significantly different are followed by the same number (significance level at LSD $5 \%)$

The number of rotten fruit from each AMF treatment showed no significant difference $(\mathrm{P}<0,05)$. Based on the observation of the symptoms of disease attack on the fruit, it is possible that the pathogen that attacks the fruit is Collethotrichum spp. with an average range of 1-4 rotten fruit per plant (Table 1) The average percentage of rotten fruit ranged from 2.04 $(9 \mathrm{~g} / \mathrm{plant})$ to $11.28 \%(0 \mathrm{~g} / \mathrm{plant})$.

The role of AMF as an agent that helps the formation of plant resistance to pathogen attack is seen in the treatment dose of 9 g/plant, which according to Dwivedi et al. [20] Youssef and Eissa [21], in addition to increasing the root surface area so that it plays an important role in the process of absorption of nutrients from the soil, AMF (endomycorrhiza type) can increase plant resistance to pests and diseases. The AMF is present in $>86 \%$ of plant species and when the hyphae penetrate the cortical cells of the plant roots, they form intracellular arbuscular [22]. This structure will help the formation of plant resistance through the synthesis of phenolic compounds and others. In addition, AMF can also facilitate the detoxification of organic and inorganic soil pollutants that can harm crop productivity [23]. 


\subsection{Analysis of the Root Components}

Measurement of the roots of cayenne pepper plants is important to do to find out whether there is colonization or infection with AMF. The length and root weight of capsicum frutescens was affected by the application of AMF, where at a dose of $9 \mathrm{~g} / \mathrm{plant}$ JMA produced the highest root length, wet root weight, and mycorrhizal infection (Table 2). The results of this study are by the statement Youssef et al. [21] which states that AMF can increase the growth of plant root systems. AMF hyphae also increase the absorption of phosphorus (P) and other nutrients and increase root and shoot length [24]. Application of AMF 4 g/plant and 6 g NPK fertilizer increased root surface, root length, root wet weight, and nitrate reductase activity [25].

Table 2. Description of the root components of Capsicum frutescens

\begin{tabular}{|c|c|c|c|c|}
\hline No. & Treatment & $\begin{array}{c}\text { Root length } \\
(\mathbf{c m})\end{array}$ & $\begin{array}{c}\text { Root wet weight } \\
(\mathbf{g})\end{array}$ & $\begin{array}{c}\text { Mycorrhizal infection } \\
\text { of the roots (\%) }\end{array}$ \\
\hline 1. & M0 & $50 \mathrm{~b}$ & $32.5 \mathrm{~b}$ & $21 \mathrm{c}$ \\
\hline 2. & M1 & $61 \mathrm{~b}$ & $50 \mathrm{~b}$ & $73 \mathrm{ab}$ \\
\hline 3. & M2 & $49 \mathrm{~b}$ & $40 \mathrm{~b}$ & $28 \mathrm{c}$ \\
\hline 4. & M3 & $89 \mathrm{a}$ & $87.5 \mathrm{a}$ & $94 \mathrm{a}$ \\
\hline 5 & M 4 & $77 \mathrm{ab}$ & $54 \mathrm{~b}$ & $44 \mathrm{bc}$ \\
\hline & CV (\%) & 15,29 & 17,91 & 18,76 \\
\hline
\end{tabular}

Mean which are not significantly different are followed by the same number (significance level at LSD $5 \%)$

In the roots of capsicum frutescens, AMF infection was found from $21 \%(0 \mathrm{~g} / \mathrm{plant})$ to 94\%. (9 g/plant) (Table 2). This indicates that there has been an association between AMF and the roots of capsicum frutescenss (Figure 5). There are six genera of fungi that have been shown to form mycorrhizal associations with plant roots, namely Glomus, Acaulospora, Gigaspora, Sclerocystis, Entrophospora, and Scutellospora (Sullia) [26]. Of the six AMF genera commonly found associated with plant roots, namely Glomus sp. This assumption is based on information that about $60-70 \%$ of JMA species Glomus sp. infect plant roots.
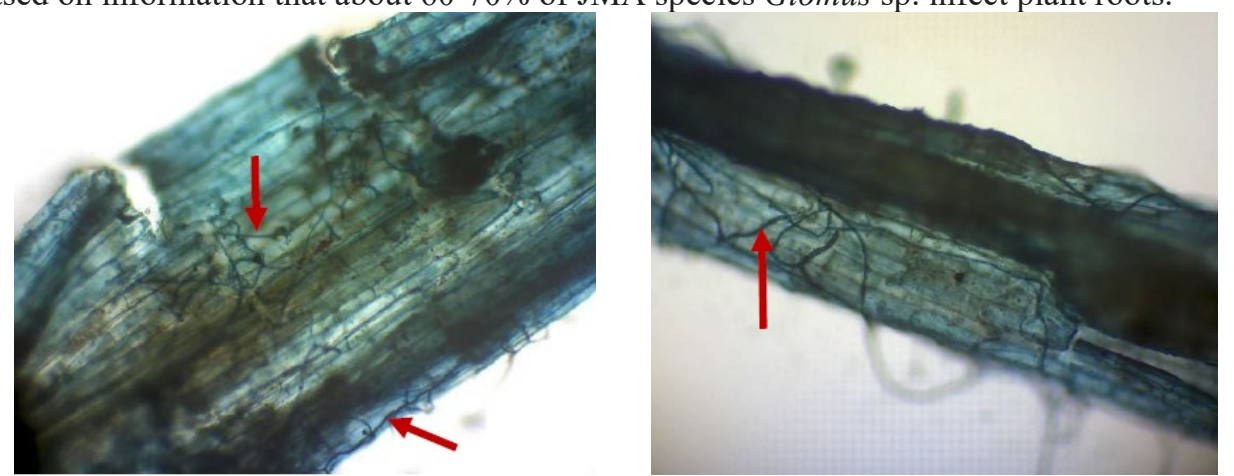

Fig. 5. Mycorrhizal infection of the roots capsicum frutescens ; internal hyphae (hyphae formed within the root tissue) are indicated by red arrows

\section{Conclusions}

The application of AMF at a dose of $9 \mathrm{~g}$ /plant can optimize plant height, number of leaves, number of fruits, fruit weight and suppress the amount of fruit rot of capsicum frutescens. A dose of $9 \mathrm{~g} /$ plant AMF can also increase root length, root wet weight and the percentage of 
plant root infection. The research implication is that the optimal dose of AMF can be a biological stimulating agent to increase plant growth and yield.

Acknowledgments. The author wishes to thank the Assessment Institute of Agricultural Technology of North Maluku, Ministry of Agriculture of Republic Indonesia for location permission of research.

\section{References}

1. W. Setiawati, Y. Kusandriani, A. Hasyim A, Sumbsangsih cabai keriting kencana dalam menghadapi kebijakan swasembada cabai, in Bunga Rampai: Inovasi Hortikultura Pengungkit Peningkatan Pendapatan Rakyat, pp 45-57, IAARD Press, (2015)

2. BPS Provinsi Maliku Utara, Data luas lahan dan produksi hortukultura, BPS Provinsi Maluku Utara, (2019)

3. Hariyadi, J. Pertan. 3 (2012)

4. Y. Saleh, C. Sugihono, I. Prambudi, Pengembangan agribisnis cabai berkelanjutan di kota Ternate, in Seminar Nasional Mewujudkan Kedaulatan Pangan Melalui Penerapan Inovasi Teknologi Pertanian Spesifik Lokasi Pada Kawasan Pertanian (2018)

5. S. Basu, R.C. Rabara, S. Negi, Physiol. Mol. Plant Phatol. 102, 36-45 (2018)

6. H. Kang, X. Chen, M. Kemppainen, A.G. Pardo, C. Veneault-Fourrey, A. Kohler, F.M. Martin, Environ. Microbiol. 22, 1435-1446 (2020)

7. A.M. Astiko, I.R. Sastrahidayat, A. Djauhari, Trop Soils. 18, 1 (2013)

8. Balai Penelitian Tanaman Palma, Manado, Hasil analisis Laboratorium Jaringan Tanaman, Balai Penelitian Tanaman Palma, Manado (2020)

9. P.P. Kormanik, A.C. Mc Graw, Methods and Principles of Mycorrhizal Research, 37-46 (APS Press, Mineapolis, USA, 1982)

10. U. Sumpena, A. Permana, Budidaya Cabai Merah dan Cabai Rawit Menggunakan Pot/Polybag, Seri KRPL (Balai Penelitian Tanaman Sayuran, Badan Penelitian dan Pengembangan Pertanian, Kementerian Pertanian, 2017)

11. A.F. Halis, P. Murni, A. B. Fitria, Biospecies. 1, 2, 59-62 (2008)

12. V. Adetya, S. Nurhatika, A. Muhibuddin, Jurn. Sains dan Seni ITS. 7, 2, 75-79 (2018)

13. M. Razaq, P. Zhang, H. Shen, Salahuddin, PLoS One. 12, 2, e0171321 doi:10.1371.journal (2017)

14. B.R. Fahmi, A. Syamsudin, S.N. Utami, Berita Biologi (2010)

15. A.M. McFarland JW., R.W. Ruess, K. Kielland, K. Pregitzer, R. Hendrick, Ecosys. 13, 177-193 (2010)

16. Nurhayati, J. Floratek. 7, 25-31 (2012)

17. N. Garg, S. Chandel, Agron. Sustain. Dev. 30, 581-599 (2010)

18. H. Bucking, A. Kafle, Jour. Agron. 5, 587-612 (2015)

19. M. Parihar, M. Chitara, P. Khati, A. Kumari, P.K. Mishra, A. Rakshit, K. Rana, V.S. Meena, A.K. Singh, M. Choudhary, Arbuscular mycorrhizal fungi: Abundance, interaction with plant and potential biological applications, in Advances in Plant Microbiome and Sustainable Agriculture, 105-143 (Springer, Germany, 2020)

20. S. Dwivedi, G.R. Sangeeta, R. Gopal, Int. J. Pharm. Bio. Sci. 6, 1014-1026 (2015)

21. M. Youssef, M. Eissa, J. Biotechnol. Pharm. Res. 5, 1-6 (2014)

22. S. Javeria, V. Kumar, P. Sharma, L. Prasad, M. Kumar, A. Varma, Mycorrhizal Symbiosis: Way underlying plant-fungus interaction, in Mycorrhiza-Eco-Physiology, Secondary Metabolites, Nanomaterials, 183-207 (Springer, Germany, 2017)

23. O.A. Fasusi, C. Cruz, O.O. Babalola, Agriculture. 11, 163 (2021)

24. H. Abbasi, A. Akhtar, R. Sharf, Am. J. Plant Nutr. Fertil. Technol. 5, 40-49, (2015)

25. W. Sulistiono, B. Brahmantiyo, S. Hartanto, H. Bayuaji, K.B. Habeahan, J. Agron. doi: $10.3923 /$ ja $(2020)$ 
26. S. Sullia, Horticulture-New Technologies and Applications, 49-53 (Springer, Germany, 1991) 